UDC 621.3.048.1

\title{
IMPROVEMENT OF THE NONEQUILIBRIUM-COMPENSATION METHOD FOR STATE DIAGNOSTICS OF HIGH-VOLTAGE APPARATUS WITH CONDENSER INSULATION
}

SAKHNO A.A.

SKRUPSKAYA L.S.

DOMOROSHCHYN S.V.
Phd, Associate professor of electric and electronic apparatus department, National University "Zaporizhzhia Polytechnic", Zaporizhzhia, Ukraine, e-mail: a.asakhno@yahoo.com;

Senior lecturer of electric and electronic apparatus department, National University "Zaporizhzhia Polytechnic", Zaporizhzhia, Ukraine e-mail: skrupskaya_ls@gmail.com;

post-graduate electric and electronic apparatus department, National University "Zaporizhzhia Polytechnic", Zaporizhzhia, Ukraine, e-mail: domoroshchin77@gmail.com.

Purpose. Investigation of the nonequilibrium-compensation method for diagnosing the state of high-voltage devices with capacitor isolation, a description of the experience of using the method, finding the disadvantages and advantages of this diagnostic method, the development of improvements to the nonequilibrium-compensation method.

Methodology. The study was carried out by the method of continuous monitoring under operating voltage ("online") for bushings of a three-phase group of shunt reactors to a voltage class of $750 \mathrm{kV}$.

Findings. As a result of the study, the authors developed an improved mathematical model for the nonequilibriumcompensation method, which takes into account the influence of the operating voltage, and received the final formula for determining the unbalance current, which can significantly increase the reliability of the diagnosis. The improved model is different in that it takes into account additional parameters - a working three-phase voltage, under the influence of which is the insulation of electrical devices. The values of the phase and amplitude of the unbalance current obtained using the model will not depend on the network operating modes, such as asymmetry, for example, and, accordingly, there is no need to set the overshot alarm settings and equipment shutdowns, unlike the "classical" method, since the parameters change unbalance current will be caused only by changes in active losses in isolation or partial breakdown of the insulation design of the device.

Originality. The authors developed an advanced mathematical model for the diagnosis of high voltage apparatus with capacitor isolation under operating voltage. The result of the calculation of the new model does not depend on the effects of operating voltage (such as asymmetries of amplitudes and interphase angles).

Practical value. The obtained model can be used in the production of systems and devices for continuous diagnostics (monitoring) of the main insulation of high-voltage bushings at voltage classes of $110-750 \mathrm{kV}$.

Keywords: nonequilibrium-compensation method; condenser insulation; unbalance current; capacitance; tangent of dielectric losses; continuous monitoring; high voltage bushings.

\section{INTRODUCTION}

Technologic failures, due to high voltage bushings and current transformers failures are one of the most frequent and economically expensive either for grids and generating power plants. Therefore, since 1960, the scientific community and regulatory authorities have paid special attention to the diagnosis of this equipment. Over the years, manufacturing companies, power generating and electric grid enterprises, enterprises engaged in the repair and diagnostics of industrial equipment, have gained some experience in diagnosing devices in various operating modes. Nowadays, there are two most applied diagnostic methods: with taking equipment out of service under testing voltage ("offline") and continuous monitoring under operating voltage ("online"). It is more rarely applied a periodic tests under operating voltage with and without taking equipment out of service.
Automatic continuous monitoring under operating voltage has a list of advantages over other methods, such as frequency of diagnostic parameters analysis, absence of a human factor influence and operating voltage, which allows determining major defects in insulation.

The nonequilibrium-compensation (balance) method is the most widespread method of continuous monitoring under operating voltage nowadays. This method is described in the list of domestic and foreign author's works [1] - [10]. The realization of this method is different: KIV-500R (КИВ-500P) devices with adjustment transformers TPS-0.66 (TПC-0,66), modern microprocessor devices such as R1500 («Dimrus», city Perm), ZVCM Bushing Monitor (ZTZ-Service International Inc, USA) and others.

Energy companies have a big experience in exploiting of KIV-500R devices and others, based on this 
method devices and systems. However, this experience is often negative [13], [14], [15], because of false information about values of diagnostic parameters, and, correspondently, inability to make a conclusion about technical condition of apparatus.

\section{ANALYSIS OF LAST RESEARCHES}

Mathematical models developed by authors are very important for correct insulation defect detection under operating voltage. Thus, many scientists pay a great attention to this question. For example, domestic scientist $\mathrm{PhD}$ Gleb Shinkarenko in his work [13], on the examples from practice, showed that unbalance-compensating method applying is ineffective and even negative. Also negative experience of sum-of-current method is shown in [13], [14], [15], because of false information about values of diagnostic parameters, and, correspondently, inability to make a conclusion about technical condition of apparatus. Improved model for this method is stable for asymmetry of amplitudes and interphase angles of operating voltages. So it can used for increasing of reliability of this diagnostic method.

\section{FORMULATION OF THE WORK PURPOSE}

The aim of this article is analysis of negative experience causes of nonequilibrium-compensation method applying for diagnostic of condition of high voltage condenser insulation and presentation of method improvement results.

\section{EXPOSITION OF THE MAIN MATERIAL AND RESULTS ANALYSIS}

Nonequilibrium-compensation method is based on two suggestions:

- three-phase voltage system is symmetric;

- diagnostic parameters of three apparatus of threephase group can't be changed at the same time and in equal degree.

This method means a geometric sum of three leakage current vectors of the main insulation. In ideal case, if the condition and capacities of the main insulation of three apparatus are equal and the three-phase voltage system is symmetrical (the amplitudes are equal, and the interphase angles are $120^{\circ}$ ), the total current will be zero. With an increase in active losses or a change in the insulation capacity, the phase and amplitude of the current will change, and this will lead to the appearance of a current other than zero - an imbalance that can be measured by a diagnostic tool.

The amplitude value of the total current quantitatively determines the degree of defect in the insulation, and its angle indicates the phase of the device with the defect.

Such ideal situation never happens in practice, therefore in order to balance vector in zero different solutions can be applied, for instance, instrument transformers, which can change amplitudes of current leakage vec- tors, and in case of microprocessor devices it changes balanced coefficients, which are used for dovetailing of amplitude and phase of vectors.

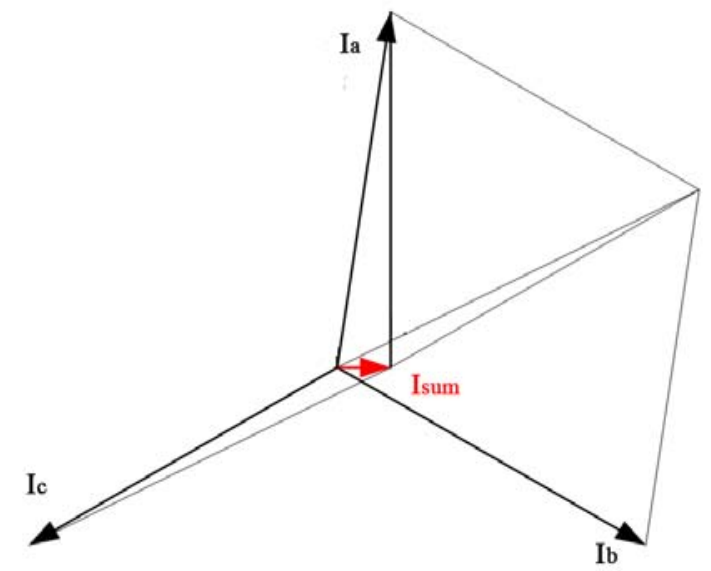

a)

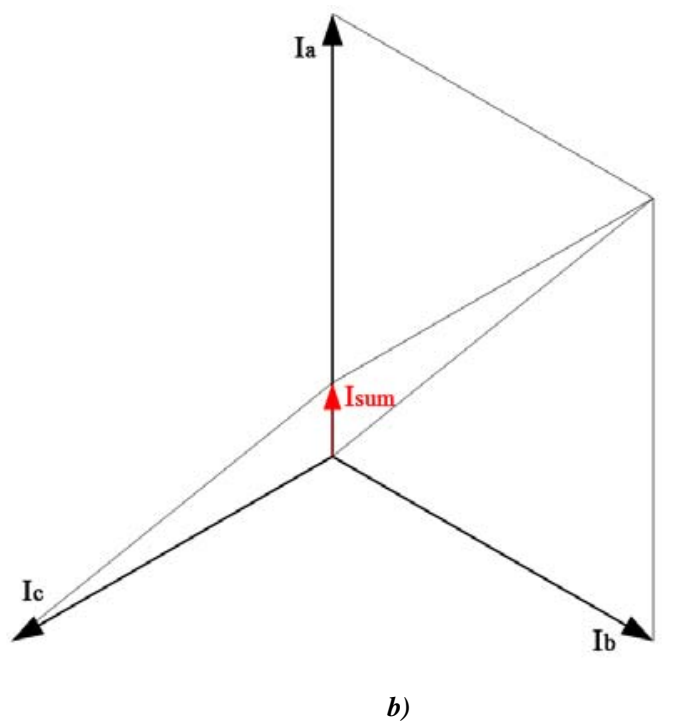

a) - Isum (sum-of-currents) is caused by active losses increase in insulation of apparatus " phase " $A$ "

b) - Isum is caused by shunting of the main insulation part of apparatus' phase " $A$ "

Figure 1. Unbalanced current appearance

Devices, based on this method, indicate tangent of dielectric losses and capacities of the main apparatus insulations except indication of unbalanced vector's amplitude and phase.

Insulation leakage current vector depends on vectors of voltages, applied to this insulation, active losses and capacity of the main insulation. Correspondently, unbalanced current vector depends on 9 parameters:

$$
\overrightarrow{I_{H}}=f\left(\vec{U}_{a}, \vec{U}_{b}, \vec{U}_{c}, C_{1 a}, C_{1 b}, C_{1 c}, \operatorname{tg} \delta_{1 a}, \operatorname{tg} \delta_{1 b}, \operatorname{tg} \delta_{1 c}\right)
$$

Thus, the mathematical calculation to determine the tangent of the dielectric loss angle and the main insulation capacitance based on this method is poorly substantiated and ineffective For such calculations, some diagnostic 
tools use certain assumptions to solve a system of two equations with 12 unknown parameters In order to provide the solution of such system of equations producers of devices apply different algorithms of adaptation to the modes of network and equipment operation. The described problems lead to the wrong solutions of system, since it is impossible to take into account all these factors in real-time mode:

- changes in loads and other factors that can cause voltage changes cannot be reliably predicted nized;

- insulation aging of different devices isn't synchro-

- different devices can have different temperatures of insulation;

- different objects can have different paces of natural insulation aging.

There was a monitoring of bushing operation by $\mathrm{R} 1500$ device, installed for the monitoring of high voltage bushings of three-phase group of single-phase shunting reactors of the POM-110000/750 type on the $750 \mathrm{kV}$ switchgear.
An increase in the values of the tangent of the dielectric loss angle of the main insulation of the bushings at phases " $A$ " and " $C$ " was recorded (fig. 2).

Twice increase of parameter value in phase "C" during short period of time (less than 10 days) is the basis for additional testing of input with taking equipment out of service. However, the detailed analysis of this case, based on the giving data from the system on the data of the SAFE-T online monitoring system (manufactured by Energy Automation Ltd, Zaporizhzhia, Ukraine), showed that this case is not the result of defects in the insulation of the bushings, but is a classic example of the disadvantages of the nonequilibrium-compensation method. In fig. 3 current leakage plots of the main insulation of three bushings are shown (points - phase "A", continuous line - phase "B", dotted line - phase "C", thick continuous line - reduced value of unbalanced vector amplitude (a relation of amplitude to the mean value of three currents amplitudes in percent)). Initial plots' analysis confirms increase of current value of insulation conduction current of bushing phase "A".

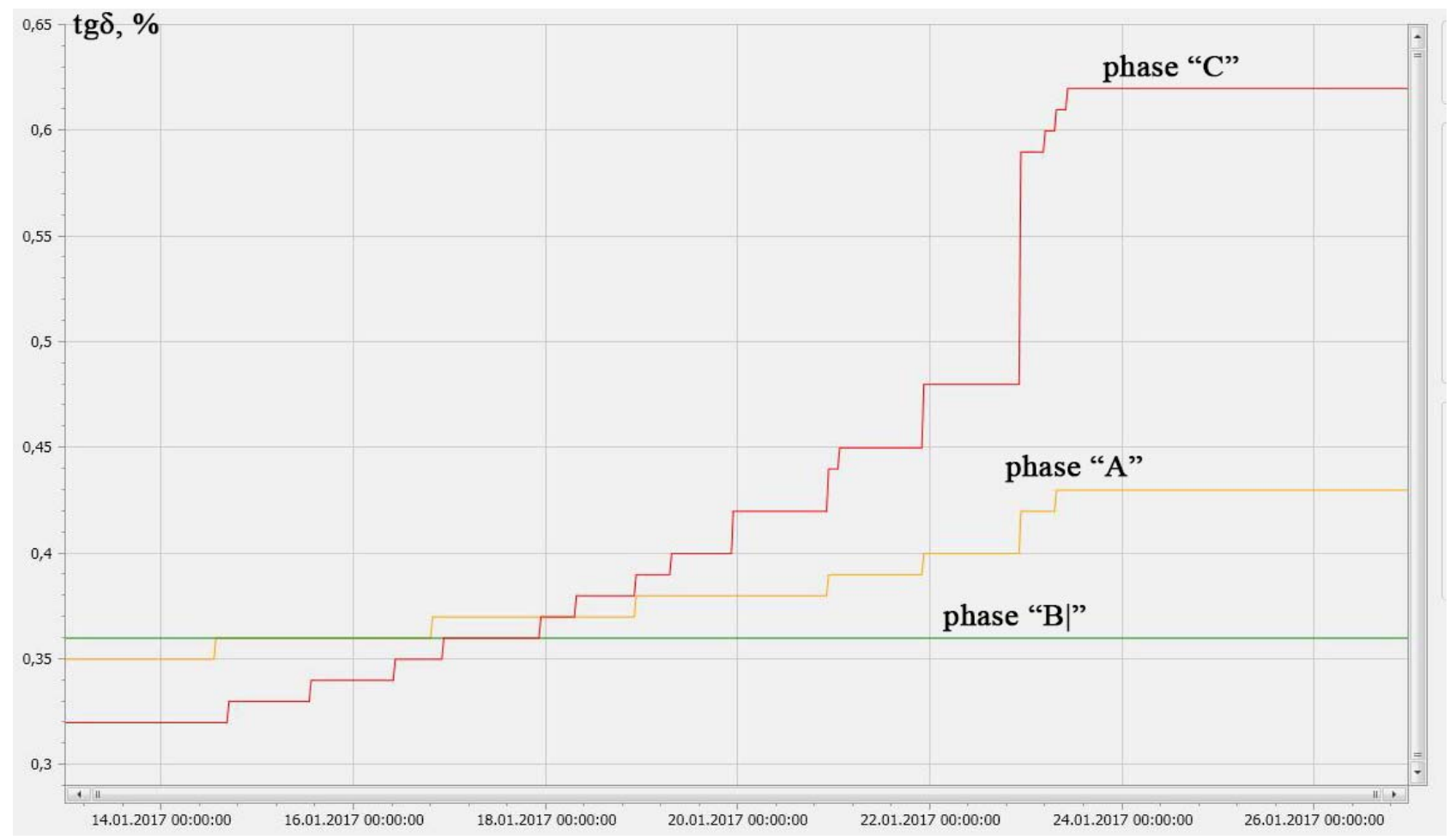

Figure 2. The results of tangent of dielectric losses of the main insulation of high voltage bushings monitoring, registered by classical nonequilibrium-compensation method (by R1500) 


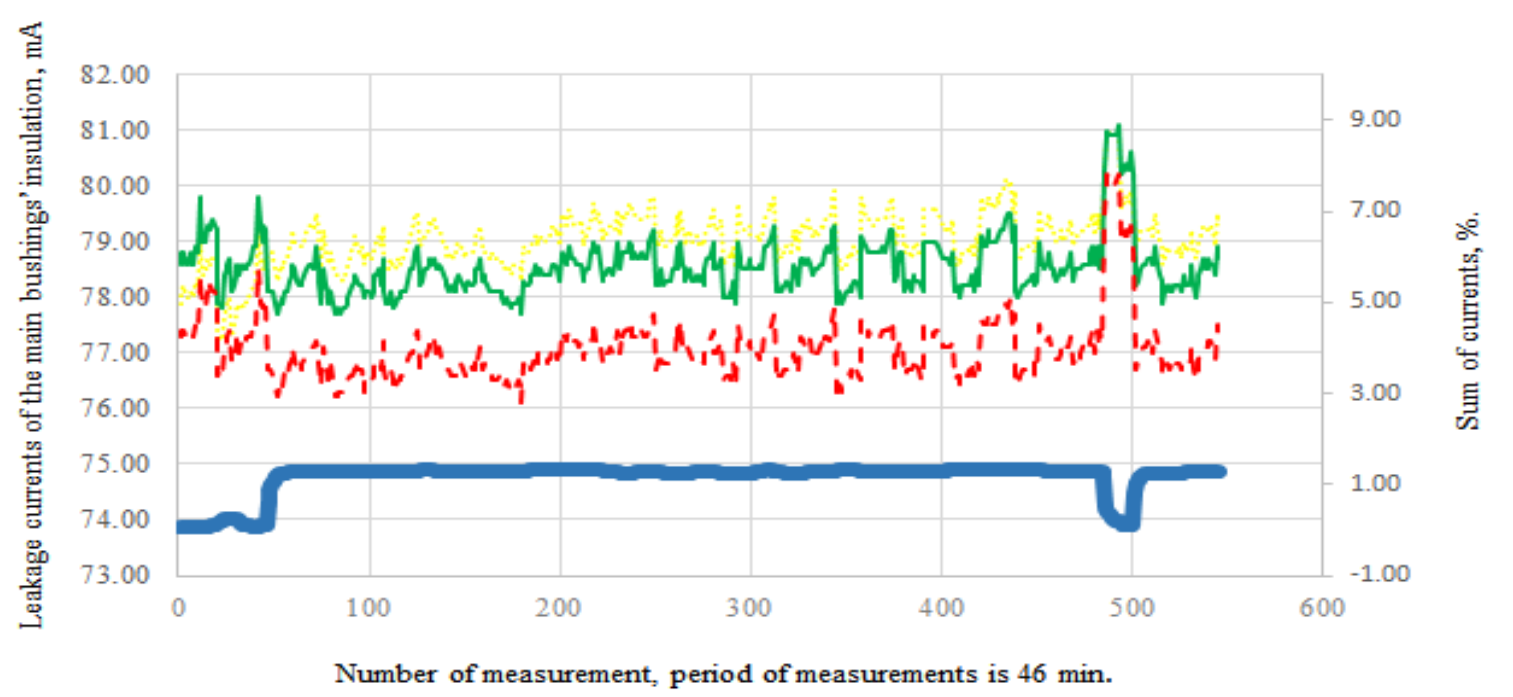

Figure 3. Leakage currents of the main bushing insulation

In fig. 4 plots of phase operating voltages changes are represented, plots are also represented change of unsented in arbitrary units only for a qualitative assessment balance voltages' vector. The voltage unbalance is pre-

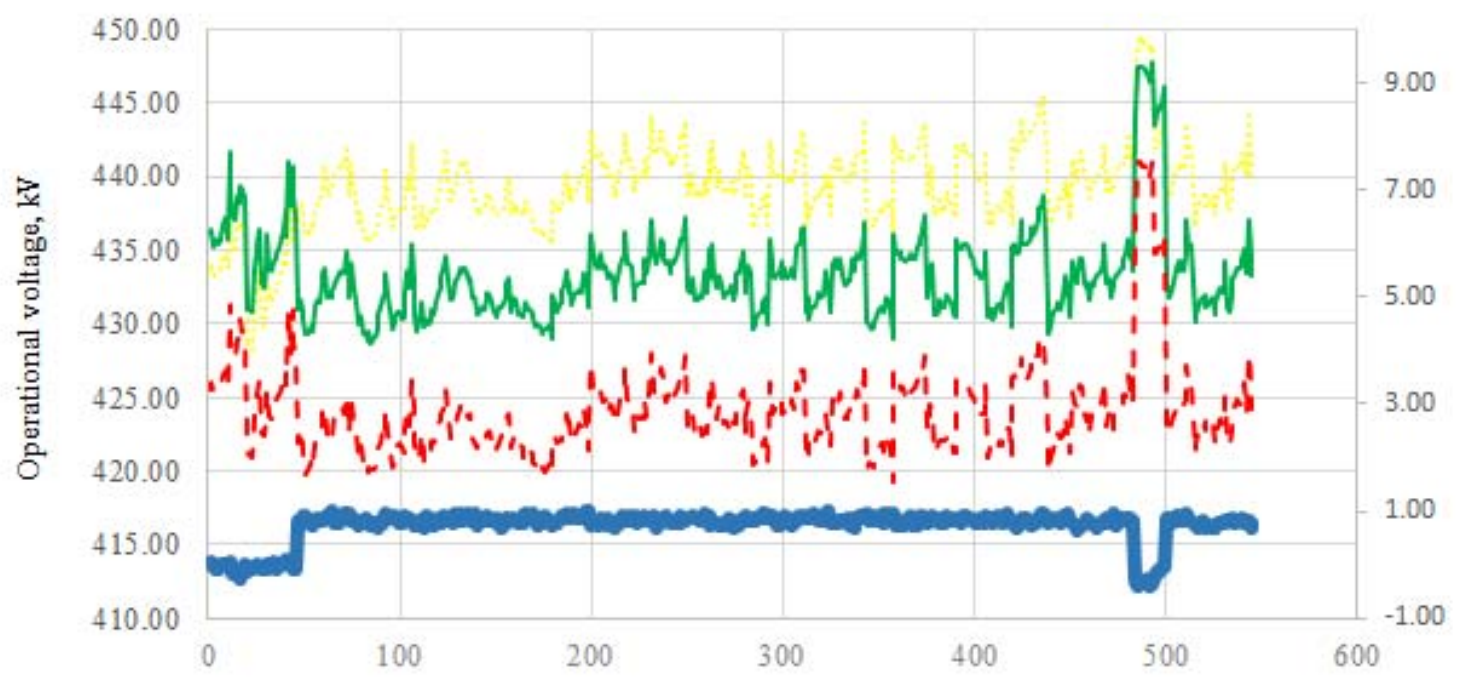

Number of measurement, period of measurements is $46 \mathrm{~min}$.

Figure 4. Phase voltages

Fig. 5 shows the graphs of load currents, these graphs qualitatively repeat the graph of leakage currents, because the winding currents change in accordance with changes in the applied voltage. An increase in the winding current (load) of the shunt reactor in phase A led to an increase in the temperature of the upper layers of oil in this reactor (fig. 6), in comparison with the other two reactors, which caused a temperature increase in the dielectric loss of the main insulation of the input of this reactor, and is normal phenomenon, that is, it is not connected with defects in isolation this input. 


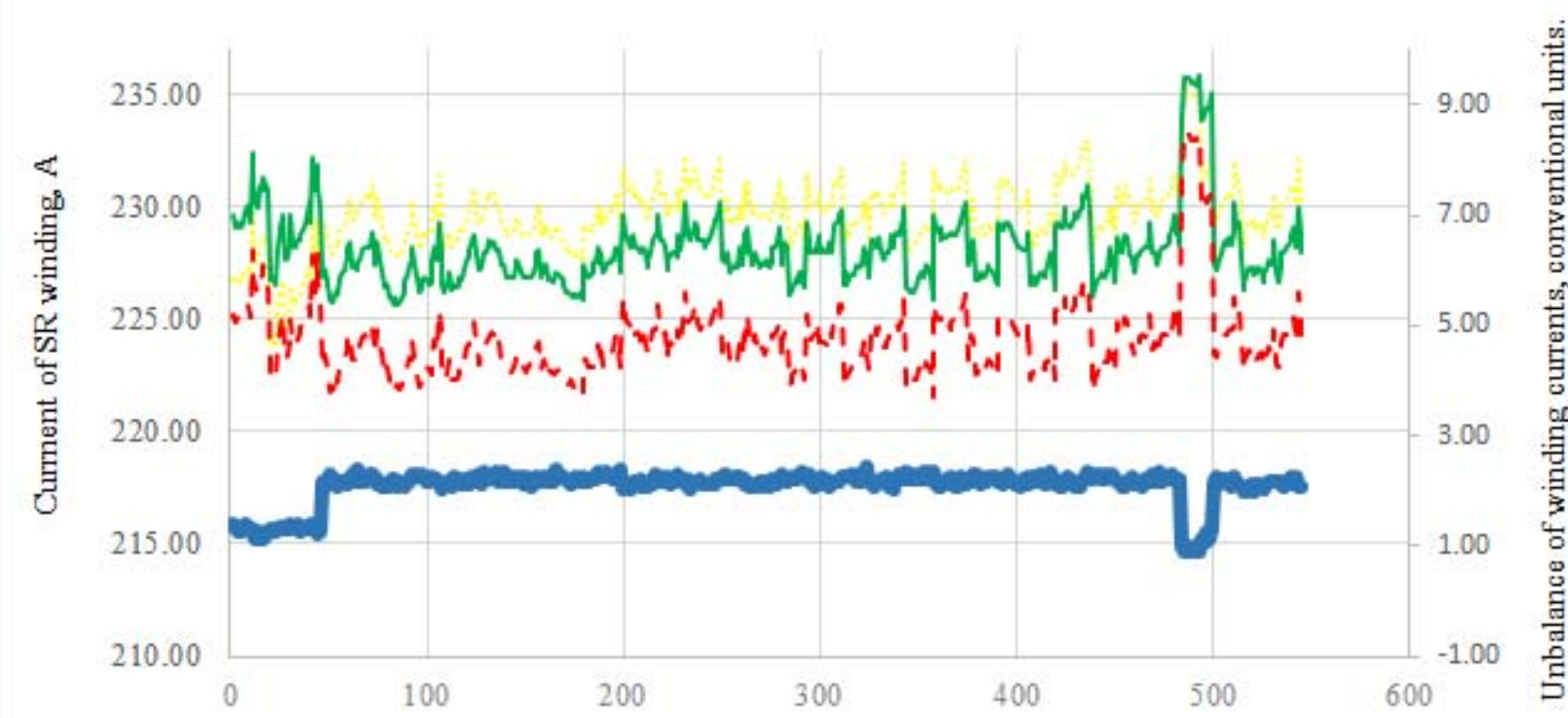

Number of measurement, period of measurements is $46 \mathrm{~min}$.

Figure 5. Reactor winding currents

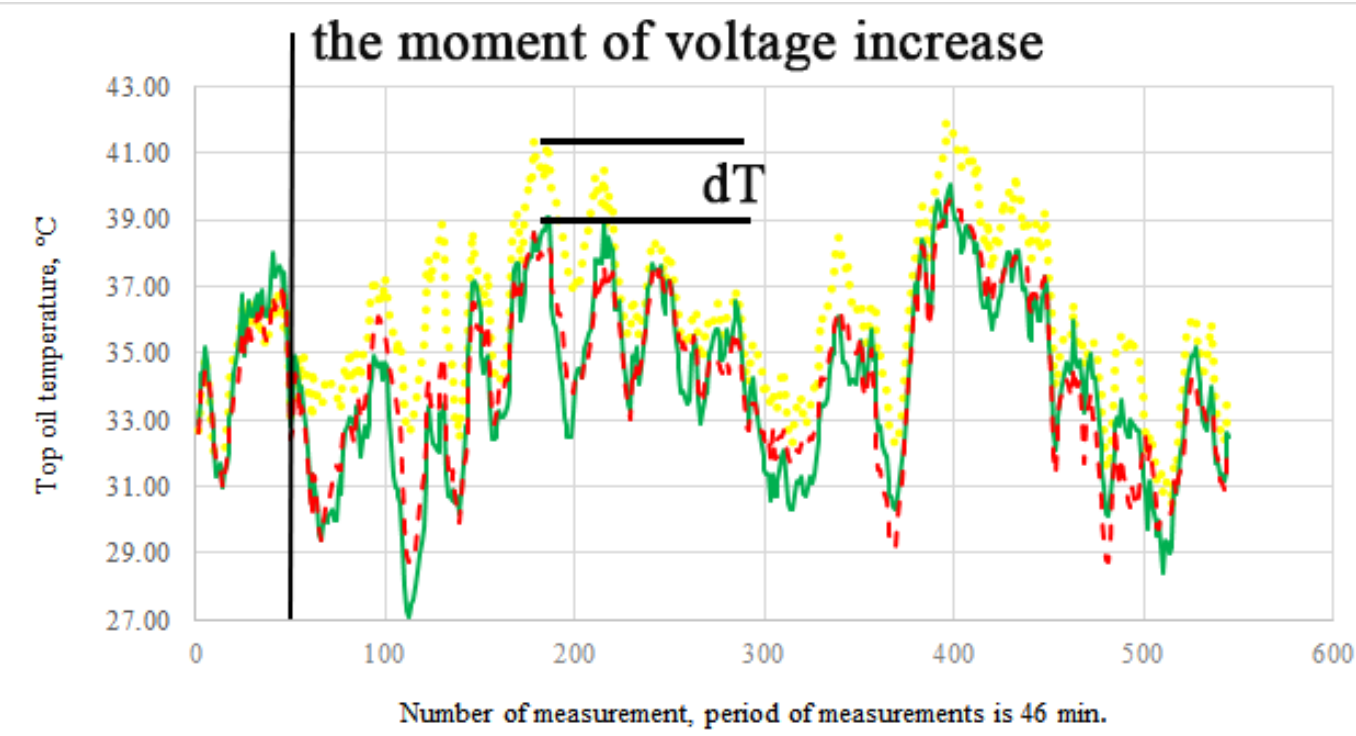

Figure 6. Temperature of upper oil layers

Thus, the analysis of the data presented in Fig. 3-6 gives a clear idea that the appearance of the unbalance vector of leakage currents (fig. 7) is due to a change in the parameters of the supply voltage.

A subsequent analysis of the network operating modes confirmed the connection of the asymmetric load to the line, which caused the indicated voltage change. Changes in the leakage currents of the bushings were caused by proportional changes in the voltages applied to the insulation of the bushings, but were not caused by changes in the technical state of the insulation of the bushings. In the fig. 7 there is represented a fixed unbalance of currents leakage of the main bushings insulation on the polar plot. Unbalance is shown by square points, where each point corresponds to the one measurement. Thus, according to explanations of the principle of unbalance vectors' appearance, which coincide with supply voltage vector of the phase " $\mathrm{A}$ " and phase " $\mathrm{C}$ " according to the direction, a small increase of active losses in bushing insulation of the phase " $\mathrm{A}$ " and more essential in bushing insulation of the phase " $C$ " were observed as well. Parameters calculation was carried out due to as- 
sumption about invariability of supply voltage vectors and bushings capacities in this case. The device accepted the assumption about capacity invariability because of the fact that capacity change causes greater current leap at its amplitude. Algorithms of device operation at calculation of insulation parameters values can differ due to different producers, however, all of them are based on non-proofed assumptions.
Thus, in this case, as well as in $99 \%$ of cases unbalance appearance was not a consequence of deterioration of bushings condition, but an influence of grid operation modes on mutual angles between phase voltages and its amplitude. All changes of these angles and amplitudes, which took place after initial balance, automatically lead to the errors in calculations and to unfounded diagnostic conclusions.

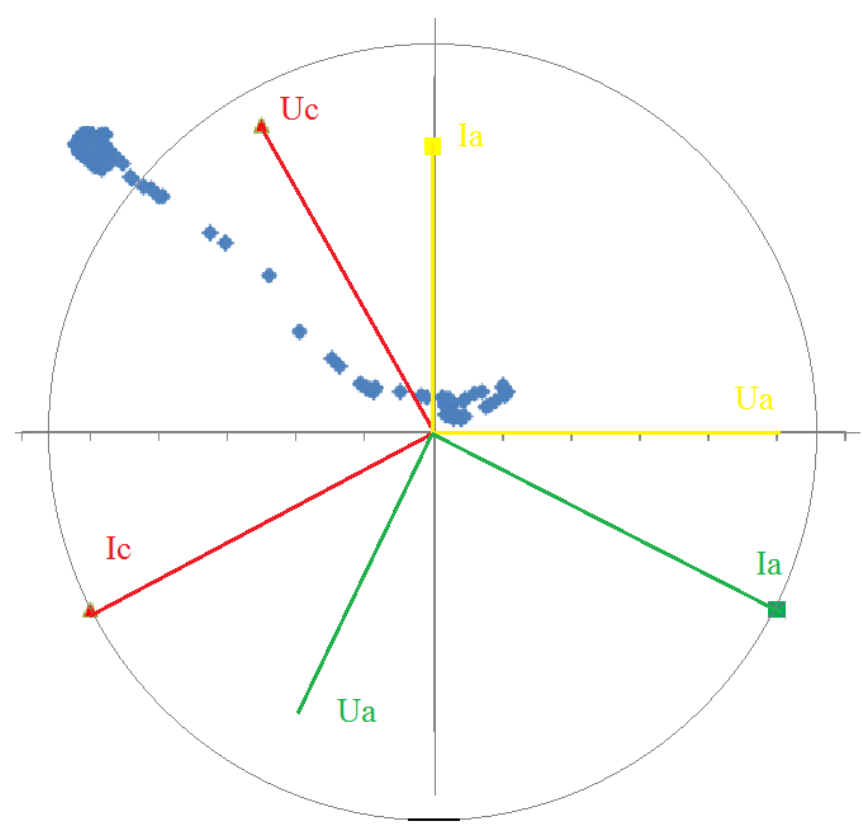

Figure 7. Polar plot of currents leakage unbalance values of the main bushings insulation

The second negative factor of the nonequilibriumcompensation method is the fact that devices, founded on it, can't detect insulation defect even on the dangerous stage of progress, because pre-emergency setting of such devices is $3 \%$, emergency setting is $5-7 \%$ from rated current of complex insulation conductivity. In practice, there are higher values of these settings, and it often leads to the fact that devices operation, based on unbalancecompensating method, activates firefighting system of the equipment because of bushing failure. Lower setting values in such devices lead to unfounded equipment tripping and mislead operational staff on substations. Domestic scientist Gleb Shinkarenko in his work [13], on the examples from practice, showed that unbalance-compensating method is ineffective and even negative, because of essential load on staff of diagnostic service, which is compelled to understand and detect false emergency signals from devices, based on this method. He designed a number of schemes, which allow to precise parameters of these devices according to substation operation modes on the base of "hard" relay logic. However, with consideration of modern development of microprocessor technique applying of relay logic essentially complicates realization of such diagnostic schemes. Therefore, authors offer the way of unbalance-compensating method improvement for elimination of its limitations. Method can be applied in systems and microprocessor devices of continuous control (monitoring). The gist of improvement is in the following: - signals of phase operational voltages must be connected to the device as well as current leakage ones;

- at the time of commissioning, the diagnostic tool must record and store the parameters (amplitude, initial phase) of phase voltages and leakage currents of the main insulation;

- sum of current vector value should be calculated according to the formula:

$$
\overrightarrow{I_{H}}=\frac{\left|\overrightarrow{U_{a e}}\right|}{\vec{U}_{a e}} \cdot\left[\frac{\overrightarrow{I_{a}} \cdot \overrightarrow{U_{a e}}}{\vec{U}_{a}}+\frac{\overrightarrow{I_{b}} \cdot \overrightarrow{U_{b e}}}{\vec{U}_{b}}+\frac{\overrightarrow{I_{c}} \cdot \overrightarrow{U_{c e}}}{\vec{U}_{c}}-\left(\overrightarrow{I_{a e}}+\overrightarrow{I_{b e}}+\overrightarrow{I_{c e}}\right)\right]
$$

where Uae, Ube, Uce - initial (at commissioning) values of phase voltages vectors (phases "A", "B", and "C" correspondently);

Iae, Ibe, Ice - initial (at commissioning) values of currents leakage vectors of the main bushings insulation (phases "A", "B", and "C" correspondently);

$\mathrm{Ua}, \mathrm{Ub}, \mathrm{Uc}-$ measured values of phase voltages vectors (phases "A", "B", and "C" correspondently);

Iae, Ibe, Ice - measured values of current leakage vectors of the main bushings insulation (phases " $A$ ", " $B$ ", 
and "C" correspondently).

Word "initial" means - at the moment of first turning of monitoring device.

Received by this method values of phase and amplitude of unbalance vector will not depend on modes of grid operation, and accordingly there is no need to set too high operation settings of alarms.

\section{V.CONCLUSION}

Nonequilibrium-compensation monitoring method of insulation condition had a wide spread because of the realization simplicity, however, due to limitations, which are observed in this work, devices, based on it, do more harm than benefit due to the unfounded load on diagnostic staff of power facilities. Offered in the work improved unbalance-compensating method allows to avoid the main lacks of classical method. However, both at using of classical method and at improved one, at estimation of bushings insulation condition it should be based only on the amplitude value and the unbalance vector phase, rather than calculation parameters: tangent of dielectric losses and capacity of the main insulation. Thus, in classical method the calculation of these parameters is carried out by solution of the system with two equations and twelve unknowns, and in improved method - two equations and six unknowns. Also during designing of monitoring device, it is necessary to pay attention on galvanic isolation of the circuits from different bushings (especially during monitoring of single-phase equipment's insulation) for exclusion of the influence of ground points nonequipotential. It is also necessary to pay attention on connection schemes, elements of insulation protection of capacitive test-tap from overvoltages and from cable break to monitoring device, because the existing connection schemes are often sources of additional errors for monitoring, and are sometimes cause of high voltage bushings failure.

\section{REFERENCE}

[1] Svi P. M. Control' izolyazui oborydovaniya vusokogo napryazheniya [Control of insulation of high voltage equipment].-2-e izd., pererab. Idop. / P. M. Svi. - M. :Energoatomizdat, 1988. - 128 s.:il.

[2] Berler Z. On-line Monitoring System for HighVoltage transformer and Bushing Insulation [Elektronnui resyrs] / Z. Berler, L.Letitskaya, V.S.Rashkes [at al] // ZTZ-Services Technical Paper, 2005. - 4 s. Rezhum dostypa: www.ztzservice.com.

[3] Brusetti R. Experience with On-line Diagnostics for Bushings and Current Transformers [Elektronnui resyrs] / Robert Brusetti // International Electrical Testing Association (NETA). - 2002. - 4 s. - Rezhum dostypa

http://www.electricenergyonline.com/?page=showarti cle\&mag_ $=18 \&$ article $=139$

[4] Kane C. On-Line Transformer Diagnostics [Elektronnui resyrs]/ Claude Kane, Alexander Golubev // Electrical Diagnostic Innovations Technical Papers. -
2005. - 6 s. - Rezhum dostypa : http://www.elecdi.com/technicalpaper.html.

[5] Zhuvodernikov S. V Diagnostika izolyazui vvodov I transformatorov toka vusokogo napryazheniya [Diagnostic of insulation of high voltage bushings and current transformers] / S. V. ZhuvodernikovA. G. Ovsyannikov,V. A. Rysov // Energoekspert. - 2009. - №1. - S. 26-29.

[6] Konyaev A. A. Izmeritelno-informazuonnaya Sistema dlya kontrolya sostoyaniya oborydovaniya s bymazhno-maslyanoi izolyazuei kondensatornogo tipa [Measuring-informational system for control of equipment condition with paper-oil insulation of condenser type], [Elektronnui resyrs] / A. A. Konyaev // Technicheskaya dokymentazuya ZAO «Prom elektronika». - 6 s. - Rezhum dostypa : http://www.prel.ru.

[7] KrulovI. P. Avtomatizirovannaya sistema diagnostiki oborydovaniya $\mathrm{s}$ bymazhno-maslyanoi izolyazuei kondensatornogo tipa [Automotive system of equipment diagnostic with paper-oil insulation of condenser type], [Elektronnui resyrs] / I. P. Krulov, Yu. A. Ryumin, A. B. Shteingayer[i dr.] - 2004. - 6 s.Rezhum dostypa : http://rza.socdu.ru/2009/tezis2004/096_promel.pdf

[8] Kyzhekov S. L. O kontrole sostoyaniya bymazhnomaslyanoi izolyazui kondensatornogo tipa transformatorov toka $110 \mathrm{kv}$ I vushe [About control of paperoil insulation of condenser type condition of current transformers $110 \mathrm{kV}$ and above] / S. L. Kyzhekov, N. R. Chymax // Energetik. - 2007. - № 1. - S. 37-39.

[9] Kyzhekov S. L. Sistema zash'tu maslonapolnennux transformatorov toka I vvodov silovux transformatorov KTУ-5 [System of oil-filled current transformers and power transformers bushings protection] [Elektronnui resyrs] / S. L. Kyzhekov, N. R. Chymak [i dr.]. - OOO NPF «Kvazar». Rezhum dostypa: ftp://ftp.soups.ru/RZA/dobav_dokl/Кужеков\%20Квазар.doc

[10]Osobennosti izmereniya parametrov vvodov pod rabochim napryazheniem [Features of bushings parameters measuring under operation voltage]. Metodicheskoe posobie. - Perm': PVF «Vibro-zentr», 2004. - 16 s.

[11]Pat. US 6.177.803 B1 United States Patent, МПК G01R 31/42, 324/551, 552, 334/557, 662, 541, 691. Monitoring Elements in a Multi-Phase Alternating Current Network / D. Traine, Ph. Guggenberg, G. Cavigelli .; zayavitel' I patentoobladatel' : Double Engineering Company Watertown, MA, US, \#08/475.407; zayavl. 07,07.1995; opybl. 23,01.2001, $-12 \mathrm{~s}$.

[12] Sistema kontrolya tokov provodimosti I tangensa ygla poter' maslo napolnennux vvodov pod rabochim napryazheniem R1500 [Control system of currents conductivity and tangent of dielectric losses of oil- 
filled bushings under operation voltage R1500]. Rykovodstvo pol'zovatelya. - Perm': PVF «Vibro-zentr», 2004. $-32 \mathrm{~s}$.

[13]Shinkarenko G. V. Kontrol' opornux transformatorov toka I vvodov silovux transformatorov pod rabochim napryzheniem $\mathrm{v}$ energosistemax Ykrainu [Control of supporting current transformers under operation voltage in the energosystems of Ukraine] / G. V. Shinkarenko // Elektricheskie stanzui. - 2001. - №5. - S. 55-62.

[14]Stirl T. Condition Monitoring and Diagnosis for Power Transformers their Bushings, Tap Changer and Insulation System [Elektronnui resyrs] / Tobias Stirl, Raimund Skrzypek, Stefan Tenbohlen [at al] // CMD,Changwong, Korea. - 2006. - 6 s. - Rezhum dostypa: http://www.uni-stuttgart.de/ ieh/forschung/veroeffentlichungen/On-line.
[15]Mordkovich A.G. O postroenii podsistem monitoring, ypravleniya I diagnostiki oborydovaniya podstanzui sverxvusokogo napryzheniyai ix integrazui $\mathrm{v}$ ASYTPPS [About the creation of monitoring subsystems, control and diagnostic of substations equipment of ultra high voltage and its integration in ASYTPPS] / A. G. Mordkovich, P. A. Gorozhankin // Elektricheskiestanzui. - 2007. - № 6. - S. 30-38.

[16]Metodicheskie ykazaniya po texnicheskomy obslyzhuvaniyu ystroistva KIV [Methodical instructions of device KIV technical service] :MY 34-70-39-83. [vveden1983-08-01]. — M. :SPOSoyuztexno, 1983 $32 \mathrm{~s}$.

Стаття надійшла до редакиії.10.12.2019

\section{ВДОСКОНАЛЕННЯ НЕРІВНОВАЖНО-КОМПЕНСАЦЙНОГО МЕТОДУ ДІАГНОСТИКИ СТАНУ ВИСОКОВОЛЬТНИХ АПАРАТІВ 3 КОНДЕНСАТОРНОЮ ІЗОЛЯЦІЮЮ}

CAXHO A.A.

СКРУПСЬКА Л.С. канд. техн. наук, доцент, доцент кафедри електричних та електронних апаратів Запорізького національного університету, Запоріжжя, Україна, e-mail: a.asakhno@yahoo.com

старший викладач кафедри електричних та електронних апаратів Запорізького національного університету, Запоріжжя, Україна, e-mail: skrupskaya_ls@gmail.com

ДОМОРОЩИН С.В. аспірант кафедри електричних та електронних апаратів Запорізького національного технічного університету, Запоріжжя, Україна, e-mail: domoroshchin77@gmail.com

Мета роботи. Дослідження нерівноважно-компенсаційного методу діагностики стану високовольтних апаратів з конденсаторною ізоляцією, опис досвіду використання методу, знаходження недоліків та переваг иььгго методу діагностики, розробка вдосконалення нерівноважно-компенсаційного методу.

Методи дослідження. Дослідження було виконано методом неперервного контролю під робочою напругою (“онлайн”) для вводів трьох-фазної групи шунтуючих реакторів напругою $750 \kappa B$.

Отримані результати. В результаті проведеного дослідження автори розробили вдосконалену математичну модель для нерівноважно-компенсаційного методу, яка враховує вплив робочої напруги, $і$ отримали остаточну формулу для визначення струму небалансу, яка дозволяє значно підвищити достовірність діагностики. Покращена модель відрізняється тим, щчо враховує додаткові параметри - робочу трифазну напругу, під впливом якої знаходиться ізолячія електричних апаратів. Отриман за допомогою иієї моделі значення фази $i$ амплітуди струму небалансу не залежатимуть від режимів роботи мережі, таких як асиметрія, наприклад, $i$, відповідно, немає необхідності встановлювати завищені уставки спрацьовування аварійних сигналів, на відміну від «класичного» методу, оскільки зміни параметрів струму небалансу будуть викликані тільки змінами активних втрат в ізоляиії або частковим пробоєм ізоляичійної конструкиії електричного апарата.

Наукова новизна. Автори розробили вдосконалену математичну модель для діагностики апаратів високої напруги з конденсаторною ізолячією. Результат нової моделі не залежить від впливів робочої напруги (таких як асиметрія амплітуд і межфазових кутів).

Практична цінність. Отримана модель може бути використана в розробиі систем та пристроїв для неперервної діагностики (моніторингу) стану головної ізоляції апаратів з конденсаторною ізоляцією на класи напруги $110-750 \kappa B$.

Ключові слова: нерівноважно-компенсачійний метод; конденсаторна ізолячія; струм небалансу; ємність, тангенс кута діелектричних втрат, неперервний контроль, високовольтні вводи. 


\section{СОВЕРШЕНСТВОВАНИЕ НЕРАВНОВЕСНО-КОМПЕНСАЦИОННОГО МЕТОДА ДИАГНОСТИКИ СОСТОЯНИЯ ВЫСОКОВОЛЬТНЫХ АППАРАТОВ С КОНДЕНСАТОРНОЙ ИЗОЛЯЦИЕЙ}

CAXHO A.A.

СКРУПСКАЯ Л.С.

канд. техн. наук, доцент, доцент кафедры электрических и электронных аппаратов Запорожского национального университета, Запорожье, Украина, e-mail: a.asakhno@yahoo.com

старший преподаватель кафедры электрических и электронных аппаратов Запорожского национального университета, Запорожье, Украина, e-mail: skrupskaya_1s@gmail.com

ДОМОРОЩИН С.В. аспирант кафедры электрических и электронных аппаратов Запорожского национального технического университета, Запорожье, Украина, e-mail: domoroshchin77@gmail.com

Цель работы. Исследование неравновесно-компенсационного метода диагностики состояния высоковольтных аппаратов с конденсаторной изоляцией, описание опьта использования метода, нахождение недостатков и преимуществ этого метода диагностики, разработка усовершенствования неравновеснокомпенсаиионного метода.

Методы исследования. Исследование было проведено методом непрерывного контроля под рабочим напряжением (“онлайн”) для вводов трех-фазной группы шунтирующих реакторов на класс напряжения $750 \kappa B$.

Полученные результаты. В результате проведенного исследования авторы разработали усовершенствованную математическую модель для неравновесно-компенсационного метода, которая учитывает влияние рабочего напряжения, и получили окончательную формулу для определения тока небаланса, которая позволяет значительно повысить достоверность диагностики. Улучшенная модель отличается тем, что учитывает дополнительные параметры - рабочее трехфазное напряжение, под воздействием которого находится изоляиия электрических аппаратов. Полученные этой моделью значения фазы и амплитуды тока небаланса не будут зависеть от режимов работы сети, таких как асимметрия, например, и, соответственно, нет необходимости устанавливать завышенные уставки срабатывания аварийных сигналов, в отличие от "классического» метода, поскольку изменения параметров тока небаланса будут вызваны только изменениями активных потерь в изоляции или частичным пробоем изоляционной конструкции устройства.

Научная новизна. Авторы разработали усовершенствованную математическую модель для диагностики аппаратов высокого напряжения с конденсаторной изоляцией под рабочим напряжением. Результат вычисления новой модели не зависит от влияний рабочего напряжения (таких как асимметрии амплитуд и межфазовых углов).

Практическая иенность. Полученная модель может быть использована в разработке систем и устройств для непрерывной диагностики (мониторинга) основной изоляции аппаратов с конденсаторной изоляцией для классов напряжения $110-750 \kappa B$.

Ключевые слова: неравновесно-компенсационный метод; конденсаторная изолячия; ток небаланса; емкость; тангенс угла диэлектрических потерь; непрерывный контроль; высоковольтные вводы. 